\title{
Tea Plantation Dynamic in West Java Based on Productivity and Institutional Research
}

\author{
${ }^{1}$ MARENDA ISHAK $S,{ }^{2}$ SUDARSONO, ${ }^{3}$ WIDIATMAKA, ${ }^{4}$ SUDIRMAN YAHYA \\ ${ }^{1}$ Ilmu Tanah, Institut Pertanian Bogor, Bogor, Jawa Barat \\ 2,3, Ilmu Tanah, Fakultas Pertanian, Institut Pertanian Bogor, Bogor, Jawa Barat \\ ${ }^{4}$ Fakultas Pertanian, Institut Pertanian Bogor, Bogor, Jawa Barat \\ email: ${ }^{1}$ marenda_07@yahoo.co.id, ${ }^{2}$ sudarsonotnh@yahoo.com, \\ ${ }^{3}$ widiatmaka@yahoo.com, ${ }^{4}$ syahya49@yahoo.co.id
}

\begin{abstract}
The growth of Indonesian tea industry requires a serious attention. Land conversion due to weather changes is considered as one of the reasons why the tea industry decreased. This is proved by the declining of Indonesian position as tea exporting country to rank 7. The potential of Indonesian tea plantations is considered to be high due to both quality and quantity. This research is aimed to explore the relationship between production and weather conditions (rainfall, temperature, and humidity) that cause land conversion. Another aim is assessing the dynamic change of the institutional role within tea plantation in West Java. The first research was initiated by literature review and sampling of primary field, meanwhile the second research was conducted by interview and questionnaire in Bandung Regency and Cianjur Regency. The results showed that humidity factor determines the tea production in West Java. The institutional role as a weakened agent in all sector is a second finding.
\end{abstract}

Keywords: Land conversion, Tea Plantation, Tea Production, Indonesia Tea Export

\section{Introduction}

Nowadays, the tea plantations development in Indonesia should be given a a serious attention by the plantation and agriculture policy maker (society). This involves some critical things on a tea plantation in Indonesia. First of all, the tea area has been decreasing due to depreciate prices and lower national production. Secondly, the tea plantations generally occupy large land. Thirdly, Indonesian tea is highly potential exported commodities. Fourthly, weather change and anomalies force the tea plantations to be reorganized in accordance with supporting physical conditions. Fifthly, the tea plantations have ecological value, tourism, and economy. Five of these reasons become the critical points why the tea plantations should be maintained more seriously.

The tea plantations development expected to improve the people welfare, moreover the tea plantations has to be structurally more managed and controlled. Dirjenbun data (2015), showed the largest tea plantation from 1967 to 2016 is owned and controlled by the people. In this regard, it will greatly affect the progress of the village. Moreover, the people's tea plantation business has ecological impact on the environment. Based on these facts, the Indonesian ministry of agriculture encourage the revitalization and improvement of existing plantation sector. The efforts have been made by the ministries seem to have a daunting challenge from the plantation sector, especially the tea plantation. It can be seen from the lower productivity, weaker transaction in tea plantation sector, high land conversion rate of tea plantations, and declining exports.

This is a dilemma, on one side the plantation sector expected to grow and provide positive impact on village economic growth but on the other side, it is weakened. The problem that often occur is the weakening

Received: March 26, 2017, Revision: April 11, 2017, Accepted: May 19, 2017

Print ISSN: 0215-8175; Online ISSN: 2303-2499.

Accredited by DIKTI. SK Kemendikbud, No.040/P/2014, valid 18-02-2014 until 18-02-2019, Indexed by DOAJ 
of tea productivity. ITC data (2015) shows that general productivity in Indonesia decreased significantly. Some of the causes is inappropriate climatic conditions, improper fertilization process, unorganized land management, lack of proper cooperation among stakeholders and land aspects related to soil physical conditions.

According to Anwar A (2005), the plantation sector plays a strategic role, especially in rural development and territory. Plantation failure in rural development depend on three points: first, the lack of community participation and involvement in strategic programs. Second, the plantation business failed to transform their institutional and cooperate with other stakeholders. Third, it is a traditional environment. The efforts to encourage the plantation sector was unsuccessfull because adaption to the changes is less understood by the community, this causes the tea plantation sector increasingly worse.

On the other hand, the plantation sector performance generally is one of the sub-sector that plays an important role in the Indonesian economy. Since the early 1970s, the growth of the plantation subsector accelerated through various policy production, investment, exports, and other policies. Those are efforts to improve plantation subsector performance in the national economy (Dirjenbun, 2015). The plantation sector strategic role also associated with fairly large employment, provide industrial raw materials, and open up industry, service business opportunities in the countryside.

\section{Research Methods}

The research conducted in Bandung and Cianjur Regency as a tea plantation center in West Java. The first research conducted to assess the effect of climatic conditions (rainfall, temperature, and humidity) on the productivity level from 1967 to 2015 . In this research, the data obtained in secondary where production data obtained from tea plantation statistics and climate data obtained from the Gambung research center. The collected data then analyzed quantitatively. To know the relationship between productivity and climate the regression correlation analysis conducted with multiple regression analysis and the mathematical functions as follows:

Where:

$$
Y=a+b_{1} X_{1}+b_{2} X_{2}+b_{3} X_{3}
$$

$\mathrm{Y}=$ productivity (Dependent variable)
$\mathrm{X}_{1}=$ rainfall (Independent variable)

$\mathrm{X}_{2}=$ temperature (Independent variable)

$\mathrm{X}_{3}=$ humidity (Independent variable)

$b_{1}, b_{2}, b_{3}=$ regression coefficient

The second research aims to explore the influence of institutional problems on the performance of the tea plantation sector and identify institutional problems that hinder the performance of tea plantations. The research was conducted with literature study methodology, primary survey with questionnaire, and field-testing. The literature study conducted to obtain accurate data on tea plantation productivity that occurs each year. The data collected from literature study is study material for institutional studies to conclude the dynamics of occurred institutional change.

The primary survey conducted with questionnaires and interviews to validate institutional data using proportional sampling techniques. The population in this research are tea plantation farmers, entrepreneurs, plantation employees, and local governments. Data analysis performed using descriptive statistics and inferential statistics. According to Zulvera et al (2014), inferential statistics are used to analyze relationships between variables, by using Rank Spearman correlation.

\section{Tea Plantation Productivity}

In the colonial period, tea plantation is a favorite as the refreshment plant. After the independence tea plantations expropriated. Tea industry growing rapidly along with the development of the world economy. At that time, Indonesia had fifth rank of the tea exporter countries and then decreases into seventh (ITC, 2015). In 1970 the tea plantations land ranging from 98.986 with production capacity 59.924 tons per year. Tea plantation area had the largest in 1998 with land area 157.039 hectares. Unlike the land area, the highest production obtained in 1996 with total production of 169.417 tons per year.

Listed since 1998 both existing plantation area and production continues to decrease (Dirjenbun, 2015). This condition describes the land area is not always directly proportional to production. The increase in tea plantation area that started from 1987 indeed increase production, but the decrease that occurred from 1999 appears also increase production in general. Plantation area and production graphic in detail presented in 
Figure 1 and 2.

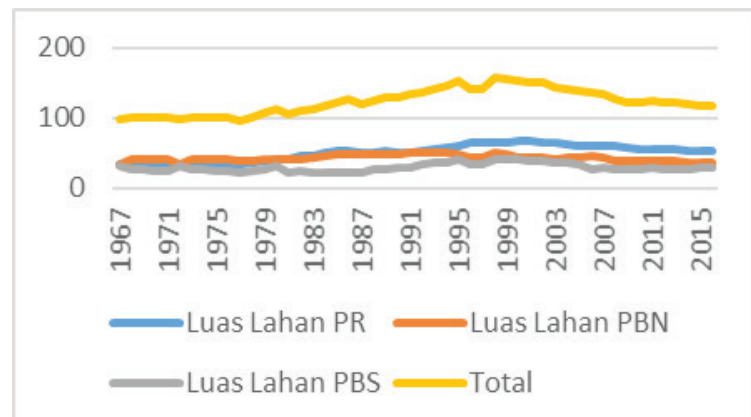

Figure 1. Tea plantations area from 1967 to 2015

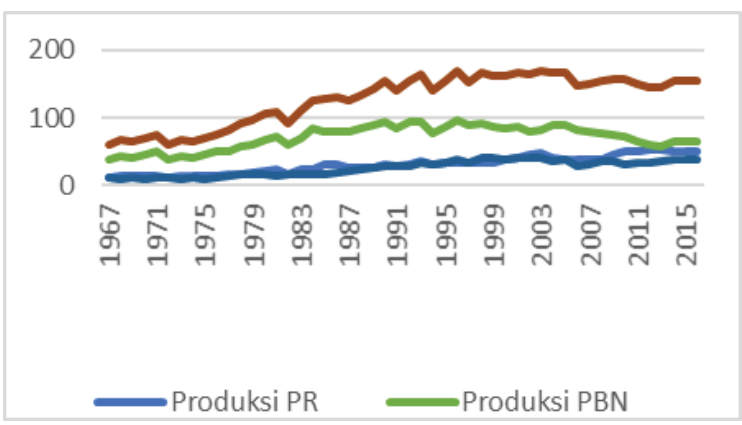

Figure 2. Tea plantations productivity from 1967 to 2015

Based on the above production data, production decrease occurred in the period 1993 - 1999 and 2004 - 2007. On one side, tea plants productivity research of all types of tea plants increasing from 1995 to 1997 and decrease in 1998 on research site (Figure 3 ). This shows that the problem of research location has close relationship with the problems occurred in Indonesia in general. Therefore, problems related in the research area will also affect the general condition of the tea plantations in Indonesia. This because the tea plantation in West Java is the largest in Indonesia, $70 \%$ of the overall tea plantations area. Still, these results can not be generalized in general, but an overview of the research sites will affect national productivity.

According writer team PS (1993),
Climatic factors that influence the tea plant growth are rainfall, air temperature, land altitude, sunlight, and wind. On the rainfall factor, tea requires a humid and cool growing area. The tea plant is not resistant to drought, therefore tea requires high and evenly rainfall area throughout the year. Optimal average rainfall for tea growth is $2500-3500 \mathrm{~mm}$ / year. In temperature factor, tea plants that originated from subtropical regions require relatively cool temperatures. Temperatures suitable for tea is $13^{\circ} \mathrm{C}-25^{\circ} \mathrm{C}$ followed by bright sunshine, with relative humidity at noon not less than 70\% (Setyamidjaja, 2000).

In this regard, physical data taken from research area are rainfall, air temperature, and humidity. The data were analyzed qualitatively and compared with tea plants grow requirements. The analysis result will describe if physical problem become the major factor of decrease in production, or there are other factors.

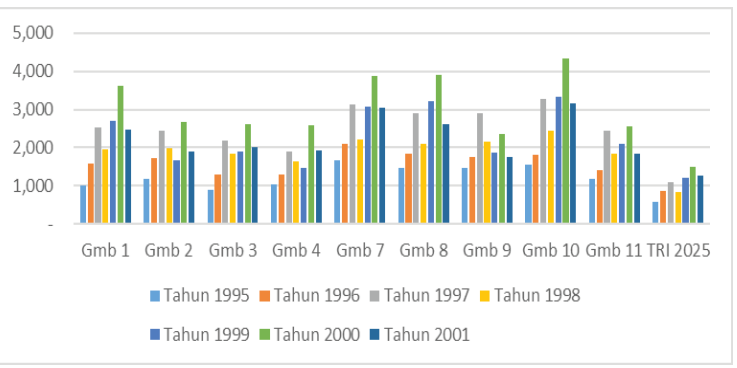

Figure 3. Tea production in Cianjur regency and Bandung Regency

As analysis illustration, the following are the data of rainfall, temperature, and humidity that directly influence the tea plantations productivity (Table 1 ).

Based on figures 1 and 2, regression result of rainfall, temperature, and humidity is $Y=38.58-0.004\left(X_{1}\right)-0.33\left(X_{2}\right)-0.34$ $\left(X_{3}\right)$. The determination coefficient $\left(R^{2}\right)$ is 0.96 or $96 \%$. This situation shows that independent variable (rainfall, temperature, and humidity)

Table 1

Rainfall, temperature, and humidity data

\begin{tabular}{|c|c|c|c|c|c|c|c|c|c|c|c|c|c|c|c|}
\hline \multirow{2}{*}{ Tahun } & \multicolumn{12}{|c|}{ Curah Hujan Per Bulan } & \multirow[t]{2}{*}{ Suhu } & \multirow[t]{2}{*}{$\mathrm{Rh}$} & \multirow[t]{2}{*}{ Produksi } \\
\hline & Jan & Feb & Mar & Apr & Mei & Juni & Juli & Agt & Sept & Okt & Nov & Des & & & \\
\hline 1995 & 272,2 & 503,0 & 481,0 & 284,9 & 287,3 & 216,6 & 181,6 & 36,8 & 142,2 & 292,7 & 637,8 & 190,3 & 20 & 89 & 1,203 \\
\hline 1996 & 382,8 & 316,3 & 386,9 & 324,1 & 66,2 & 85,4 & 103,3 & 115,8 & 138,9 & 328,9 & 562,0 & 363,4 & 19 & 89 & 1,569 \\
\hline 1997 & 418,9 & 207,2 & 245,4 & 241,1 & 142,4 & 132,2 & 12,2 & 14,4 & 60,1 & 75,0 & 277,1 & 711,6 & 19 & 87 & 2,479 \\
\hline 1998 & 344,6 & 327,8 & 536,4 & 603,3 & 294,9 & 398,5 & 275,9 & 58,3 & 217,2 & 472,9 & 332,6 & 394,6 & 19 & 87 & 1,894 \\
\hline 1999 & 286,7 & 345,0 & 279,3 & 395,3 & 130,5 & 30,7 & 28,8 & 12,0 & 3,7 & 312,5 & 347,8 & 300,8 & 20 & 86 & 2,250 \\
\hline 2000 & 335,9 & 150,0 & 198,7 & 258,4 & 239,9 & 3,2 & 59,8 & 47,8 & 99,3 & 375,4 & 492,4 & 86,5 & 20 & 85 & 3,002 \\
\hline
\end{tabular}


can affect the dependent variable (production) until $96 \%$, while $4 \%$ of other variables. Further, the most influencing factor is humidity factor $(p<0.05)$. Humidity affects the productivity significantly. The lower and higher humidity will cause the less productive tea plant. Tea plants require very specific humidity levels for optimum growth, based on statistical data the optimum humidity is in 87.2. The results showed that the humidity effect on tea productivity, this is because tea plants including plants that are vulnerable to lower humidity. Low humidity can lead to inactive tea shoots that effect to decreases productivity. In addition, low humidity pests of disease in tea are more dominant than in high humidity. Excessive humidity can also be harmful for tea plants, this is because the production and metabolism of plants be slower so that tea productivity becomes decreased. According Setyamidjadja (2000) tea plants will grow optimally on humidity less than $70 \%$. In contrast to humidity conditions, rainfall and temperature have no significant effect on production based statistical results test. It because of other factors that support optimum productivity, such as the water availability and the air availability of a good and balanced air that can help facilitate absorption of nutrients that can increase the productivity of plants, so that rainfall does not affect significantly. In this line Sarief (1986), the optimum or good growth of the plants required a state of the water and air well and balanced so that the roots of plants can easily absorb nutrients. Good water and air conditioning are when the pore is filled with minimum water of $10 \%$ and the pore is filled with minimum air of $10 \%$ or more. For further explanation can be seen in Figure 4, 5 and 6.

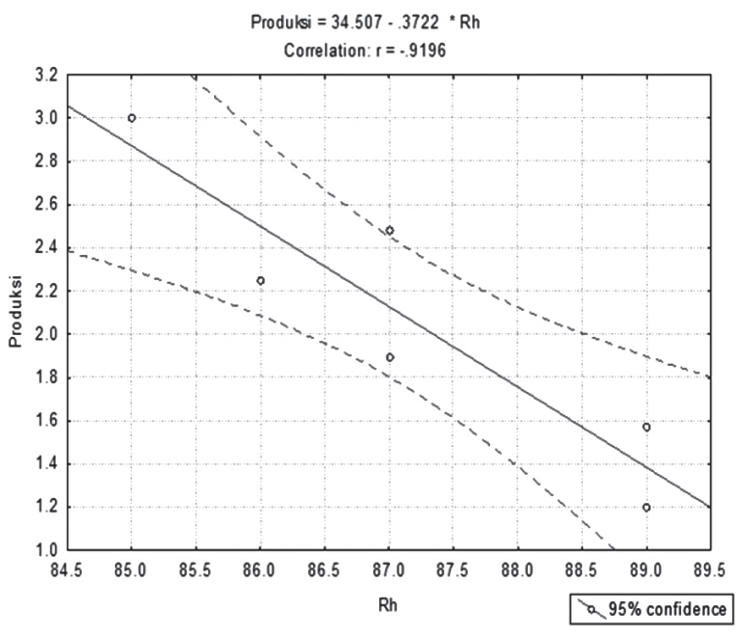

Figure 4. Tea plants humidity and production correlation

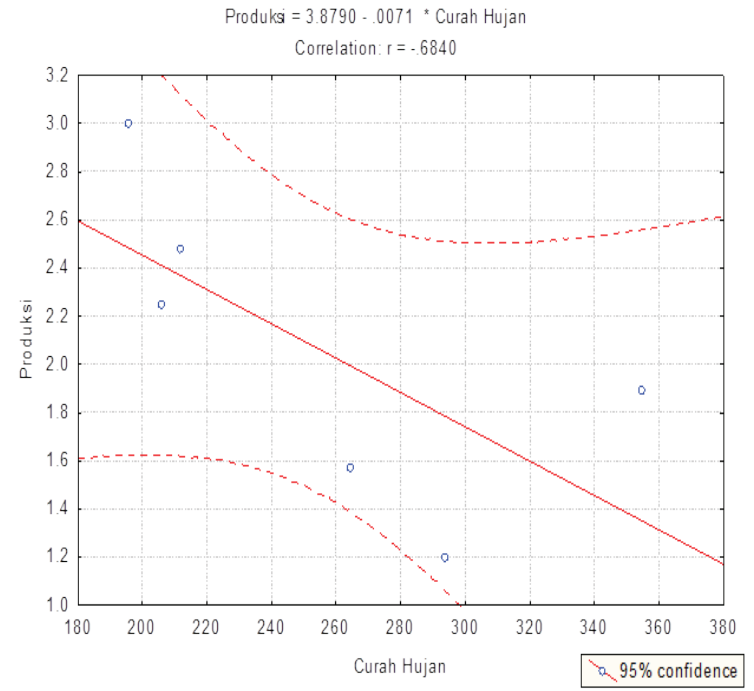

Figure 5. Tea plants rainfall and production correlation

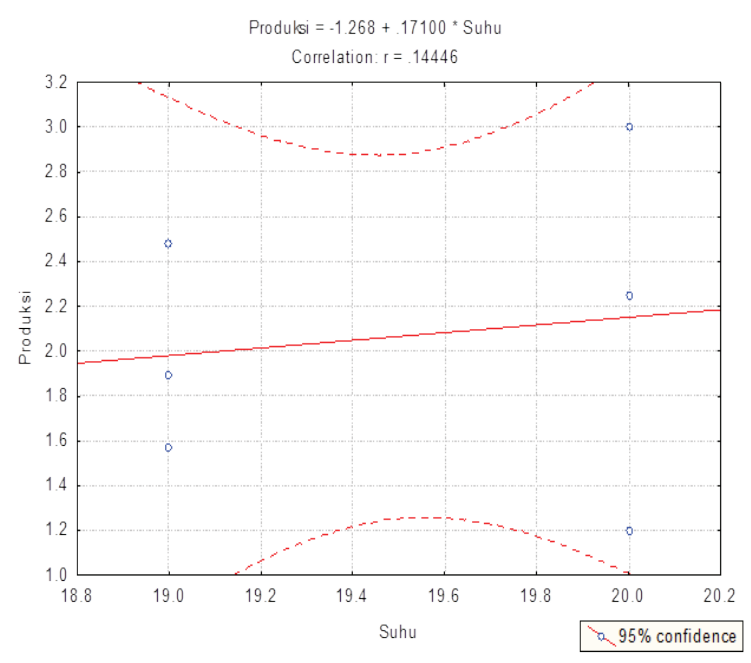

Figure 6. Tea plants temperature and production correlation

\section{Dynamics of Tea Plantation Institu- tional}

Institutional is specific norms system, which sets up a series of steady patterned actions to meet specific need of human life (Koentjaraningrat, 2004). Agricultural institutional is structured and patterned norm or customs and practiced continuously to meet the needs of community members closely related to livelihood in agriculture. A good institution is an institution that grows from below, maintained and obeyed by local people because of its high relation to the environment (Noer Melinda, 2004). Institutional in the smallholder estate production system many institutions whose role related to input access, 
financial access, market access, information and technology access, land access and institutional access.

According to Sasongko (2010) the successful cultivation of a commodity depends on the grown plants cultivar, agroecology / grown environment where cultivation do and management by farmer / entrepreneur. According to Daniel (2002) the production process can only work if the necessary requirements are met, this requirement known as production factors. Production factors consists of four components, they are land, capital, labor and skill or management. Each factor has different function and related to each other. If one factor is not available, then production processes will not run, especially the three factors mentioned above (Asnil dkk, 2010). Production factors are something that absolutely must be provided which would be perfect if all requirements are met. According to Soekartawi, 2003 production factors are all the sacrifices given to plants so that the plant will be able to grow and produce well. The success of oil palm plantations production is strongly influenced by the right combination of production factors and cultivation techniques. Production factors consists of four components, they are land, capital, labor and skill or management. These factors make synergy and influence each other in the production process.
Based on interviews and questionnaires of several institutions involved in tea plantations agribusiness system, ranging from the initial planting to processing even up to produce processed products (from upstream to downstream). Each institution has their respective roles in tea plantations agribusiness system. Institutions associated with tea plantations are Builder Company, KUD, Bank, BPN, Disbun, village government, broker, and tea processing plant, WWF, Bapedal, certification body, PPTK Gambung, and educational institutions. In the 1990s, the institutional tea in Indonesia can be said to have pretty good ability, so that people's plantations have excellent production networks. This changed after Indonesia became the seventh exporter country, such strong export competition makes the Indonesia position thrown. The impact of the significant falling exports made some very institutions, which are initially very good in response to optimizing the tea plantations become less effective even reduced.

The very visible indications are the reduction in capital aid, seeds, and fertilizers for people's tea plantations. Besides that, the number extension officers who had been routinely mentoring tea farmer become less. From interviews and questionnaires, since 2009 the various institutions roles that initially quite optimal have been weakened

Table 2

Tea plantation institutions role from upstream to downstream

\begin{tabular}{|c|c|c|c|c|c|c|}
\hline \multirow[b]{2}{*}{ Institution } & \multicolumn{6}{|c|}{ Indicator and Institution roles } \\
\hline & $\begin{array}{l}\text { Input } \\
\text { Access }\end{array}$ & $\begin{array}{l}\text { Financial } \\
\text { Access }\end{array}$ & $\begin{array}{l}\text { Institutional } \\
\text { Access }\end{array}$ & $\begin{array}{l}\text { Land } \\
\text { Access }\end{array}$ & $\begin{array}{c}\text { Access of } \\
\text { Information } \\
\text { \& Technology }\end{array}$ & $\begin{array}{l}\text { Market } \\
\text { Access }\end{array}$ \\
\hline Company Core & $\sqrt{ }$ & $\checkmark$ & $\checkmark$ & & $\checkmark$ & $\sqrt{ }$ \\
\hline KUD & $\sqrt{ }$ & $\sqrt{ }$ & & & & \\
\hline Bank & & $\sqrt{ }$ & & & & \\
\hline BPN & & & & $\sqrt{ }$ & & \\
\hline Disbun & $\checkmark$ & & $\sqrt{ }$ & $\sqrt{ }$ & $\sqrt{ }$ & \\
\hline Villages official & $\sqrt{ }$ & & $\sqrt{ }$ & $\sqrt{ }$ & & \\
\hline Broker & $\sqrt{ }$ & $\checkmark$ & & & & $\sqrt{ }$ \\
\hline \multicolumn{7}{|l|}{ Factory } \\
\hline \multicolumn{7}{|l|}{ WWF } \\
\hline Bapedal & & & & & $\sqrt{ }$ & \\
\hline Certification Bodies & & & & & $\sqrt{ }$ & \\
\hline PPTK Gambung & & & $\sqrt{ }$ & & $\sqrt{ }$ & $\sqrt{ }$ \\
\hline $\begin{array}{c}\text { Educational } \\
\text { Institution } \\
\end{array}$ & & & $\sqrt{ }$ & & $\sqrt{ }$ & $\sqrt{ }$ \\
\hline
\end{tabular}


today. This makes the tea plantations worsen. Indonesia position as the seventh also do not make Indonesian government to some improvements on the management side especially global market penetration. Negotiating position which originally initiated by BUMN become weakened, so some tea plantations lost its marketing direction. This dynamic has occurred up to now, so at some tea plantations have no longer institution with market access function. Unlike the private tea plantations that conducting market transaction personally. At this time, despite the sluggishness in the tea industry some private plantations even strengthens their bargaining position in the global market.

The role as counterpart institutions to the people's tea plantations also resulted in some tea plantations forced to manage the plant certification. As known, European and Asian markets share today require some collateral in the form of pesticides free plant certificate, social and environmental certificate, water certificate, etc. It is forgotten at some plantations so they can not enter the Europe and Asian market. In more detail, current minimal institutional role in the people's tea plantations can be seen in Table 2 .

\section{Conclusions}

The current sluggishness in tea industry development allegedly due to Indonesia failure in conducting trade transactions. The sluggishness make various institutions, which initially support the tea optimization program reduced. One of the problems that often arise in the tea industry development is the climate change / weather. Climate change considered as the cause of tea plantations land conversion. From the analysis result, tea plant production not determined by rainfall and temperature but the humidity. It has significant effect on the tea production level. Optimal humidity for the tea plant is in the range of $87.2 \%$.

\section{References}

Anwar, A. (2005). Ketimpangan Pembangunan Wilayah dan Perdesaan : Tinjauan Kritis. P4Wpress. Bogor

Arifin B. (2013). Fluktuasi Harga Komoditas Pertanian. KOMPAS 7 Januari 2013.

Asnil, S.Afifuddin, H.B. Tarmizi, W.A. Pratomo. (2010). Analisis Produksi Pendapatan dan Alih Fungsi Lahan di Kabupaten Labuhan Batu. http:// jurnalmepaekonomi.blogspot.com. [6
Januari 2016]

Badan Pusat Statitistik Jawa Barat. (2012). Jawa Barat dalam Angka. Jawa Barat: Badan Pusat Statistik

Daniel. (2002). Pengantar Ekonomi Pertanian, Bumi Aksara, Jakarta.

Dinas Perkebunan Jawa Barat. (2015). Statistik Tanaman Perkebunan Jawa Barat (tidak dipublikasikan). Bandung

Dinas Perkebunan Jawa Barat. (2012). Kajian Pengembangan Komoditas Strategis Perkebunan Teh Rakyat Jabar Tahun 2012. Bandung

EIU ViewsWire. (2013). Diakses tanggal 25 Agustus 2014.

Geng, J., Wang, W., (2005). Research progress of potassium in tea tree.Chinese Agri. Sci. Bull. 21, 175-177.

International Tea Commettee (ITC). (2015). Annual Bulletin of Statistics. International Tea Commettee. London.

International Tea Commettee (ITC). (2014). Annual Bulletin of Statistics. International Tea Commettee. London.

Koentjaraningrat. (2011). Manusia dan Kebudayaan di Indonesia. Jakarta: PT. Rineka Cipta

Noer Melinda. (2006). Pembangunan Berbasis Kelembagaan Adat: Sebuah Alternatif Pembelajaran dari Kasus Kinerja Kelembagaan Nagari dalam Wilayah Perencanaan di Propinsi Sumatera Barat. Jurnal Mimbar, Volume XXII No. 2. Pp : $234-257$

Sasongko, P. E. (2010). Studi kesesuaian lahan potensial untuk tanaman kelapa sawit di Kabupaten blitar. Jurnal Pertanian MAPETA, Vol. XII. No. 2. April 2010: 72 - 134.

Setyamidjaja. (2000). Budidaya Kelapa Sawit. Kanisius, Yogyakarta

Soekartawi, (2003). Prinsip Ekonomi Pertanian. Rajawali Press. Jakarta.

Sugiyono. (2011). Metode Penelitian pedidikan pendekatan kuantitatif, kualitatif, dan R\&D. Bandung: alfabeta

Sugiyono. (2005). Metode Penelitian Administrasi. Bandung: alfabeta

Tim penulis PS. (1993). Sayuran Komersial. Penebar Swadaya. Jakarta

Tsui, Z.S. Chen, C.F. Hsieh, Relationships between soil properties and slope position in a lowland rain forest of southern Taiwan, Geoderma 123 (2004) 131-142.

Wawan Setiawan. (1995). Koreksi Kriteria Kesesuaian Lahan Sistem CSR/FAO untuk Tanaman Teh (skripsi). Bogor : Institut Pertanian Bogor

Zulvera, Sumardjo, S Margono, G Basita. 
MiMBAR, Vol. 33, No. $1^{\text {st }}$ (June, 2017), pp. 191-197

(2014). Faktor-Faktor yang Berhubungan dengan Keberdayaan Petani Sayuran Organik di Kabupaten Agam dan Tanah Datar, Propinsi Sumatera Barat. Jurnal Mimbar, Vol 30 No. 2. Pp : 149-158 